\title{
Contribution of Hydrofluorocarbons (HFCs) and Hydrofluoro-Olefins (HFOs) Atmospheric Breakdown Products to Acidification ("Acid Rain") in the EU at Present and in the Future
}

\author{
Andy Lindley ${ }^{1}$, Archie McCulloch ${ }^{2}$, Tim Vink ${ }^{3}$ \\ ${ }^{1}$ Consultant to European Fluorocarbon Technical Committee (EFCTC), Lochmaddy, Scotland \\ ${ }^{2}$ Independent Consultant, Northwich, England \\ ${ }^{3}$ Honeywell Fluorine Products Europe, Amsterdam, Netherlands \\ Email: fluorocarbons@cefic.be
}

How to cite this paper: Lindley, A., McCulloch, A. and Vink, T. (2019) Contribution of Hydrofluorocarbons (HFCs) and Hydrofluoro-Olefins (HFOs) Atmospheric Breakdown Products to Acidification ("Acid Rain") in the EU at Present and in the Future. Open Journal of Air Pollution, 8, 81-95. https://doi.org/10.4236/ojap.2019.84004

Received: September 23, 2019

Accepted: November 4, 2019

Published: November 7, 2019

Copyright $\odot 2019$ by author(s) and Scientific Research Publishing Inc. This work is licensed under the Creative Commons Attribution International License (CC BY 4.0).

http://creativecommons.org/licenses/by/4.0/

\section{(c) (i) Open Access}

\begin{abstract}
While hydrogen fluoride (HF) and hydrogen chloride $(\mathrm{HCl})$ are not considered main air-pollutants in the EU, they have the potential to contribute to acidification. Hydrofluorocarbons (HFCs), hydrofluoro-olefins (HFOs) and hydrochlorofluoro-olefins (HCFOs) are used as refrigerants and for other applications. They break down in the atmosphere to produce $\mathrm{HF}$ and $\mathrm{HCl}$ (for HCFOs) and some of these fluorocarbons also break down to produce trifluoroacetic acid (TFA). For the emissions of these fluorocarbons in the EU, a worst-case scenario estimates their theoretical potential contribution to acidification and compares it to the acidification potential for the main air pollutants contributing to acidification, which are nitrous oxides $\left(\mathrm{NO}_{\mathrm{x}}\right)$, sulphur oxides (mainly $\mathrm{SO}_{2}$ ), and ammonia $\left(\mathrm{NH}_{3}\right)$. The Acidification Potential from these fluorocarbons in 2016 is estimated at $<0.5 \%$ of the total due to $\mathrm{SO}_{2}$, $\mathrm{NO}_{\mathrm{x}}, \mathrm{NH}_{3}$, and it can be concluded that this is insignificant in the context of the main acidification air-pollutants. Assuming that the EU targets for emissions of $\mathrm{SO}_{2}, \mathrm{NO}_{\mathrm{x}}$ and $\mathrm{NH}_{3}$ by 2030 are achieved, the Acidification Potential from HFCs, HFOs and HCFOs in 2030 is also estimated at $<0.5 \%$ of the total due to $\mathrm{SO}_{2}, \mathrm{NO}_{\mathrm{x}}, \mathrm{NH}_{3}$ and will remain insignificant.
\end{abstract}

\section{Keywords}

Hydrofluorocarbons, Hydrofluoro-Olefins, Acidification, Hydrogen Fluoride

\section{Introduction}

Hydrofluorocarbons (HFCs), hydrofluoro-olefins (HFOs) and hydrochlorofluo- 
ro-olefins (HCFOs) are used as refrigerants and for other applications. They break down in the atmosphere to produce hydrogen fluoride (HF) and hydrogen chloride ( $\mathrm{HCl}$, for HCFOs) and some of these fluorocarbons also break down to produce trifluoroacetic acid (TFA). While $\mathrm{HF}$ and $\mathrm{HCl}$ are not considered main air-pollutants in the EU, they are among the substances normally considered as potential contributors to acidification [1]:

- sulfur dioxide $\left(\mathrm{SO}_{2}\right)$

- sulfur trioxide $\left(\mathrm{SO}_{3}\right)$

- nitrogen oxides $\left(\mathrm{NO}_{\mathrm{x}}\right)$

- hydrogen chloride $(\mathrm{HCl})$

- nitric acid $\left(\mathrm{HNO}_{3}\right)$

- sulfuric acid $\left(\mathrm{H}_{2} \mathrm{SO}_{4}\right)$

- phosphoric acid $\left(\mathrm{H}_{3} \mathrm{PO}_{4}\right)$ (note: the anion does not leach and the contribution to acidification is in practice equal to zero)

- hydrogen fluoride (HF)

- hydrogen sulfide $\left(\mathrm{H}_{2} \mathrm{~S}\right)$

- ammonia $\left(\mathrm{NH}_{3}\right)$

The main air pollutants contributing to acidification in the $\mathrm{EU}$ are nitrous oxides $\left(\mathrm{NO}_{\mathrm{x}}\right)$, sulphur oxides (mainly $\mathrm{SO}_{2}$ ), ammonia $\left(\mathrm{NH}_{3}\right)$ as they form acidic species in the atmosphere, which are then rained out ("acid rain"). $\mathrm{SO}_{2}$ is used as basis for determination of the acidification potential (or the equivalency factor) for each substance. The method of establishing effect factors for acidifying substances is based on stoichiometric considerations and it is internationally accepted (see Table 1) [2].

For completeness, as TFA is an acidic breakdown product for some HFCs and HFOs, the equivalency factor for trifluoroacetic acid (TFA) is shown in Table 2 and, due to its high molecular weight, is significantly lower than those for HF and $\mathrm{HCl}$.

The trend [3] in emissions of nitrous oxides (NOx), sulphur oxides (mainly $\left.\mathrm{SO}_{2}\right)$, and ammonia $\left(\mathrm{NH}_{3}\right)$ in the $\mathrm{EU}$ and its targets [4] for 2030 are shown in Figure 1.

Table 1. Equivalency factors (EF) for acidifying substances ( $\mathrm{kg} \mathrm{SO}_{2}$-eq./substance).

\begin{tabular}{ccc}
\hline Substance & Formula & $\mathrm{EF} \mathrm{kg} \mathrm{SO}_{2} / \mathbf{k g}$ \\
\hline Sulphur dioxide & $\mathrm{SO}_{2}$ & 1 \\
Sulphur trioxide & $\mathrm{SO}_{3}$ & 0.8 \\
Nitrogen dioxide & $\mathrm{NO}_{2}$ & 0.7 \\
Nitrogen oxide & $\mathrm{NO}_{\mathrm{x}}(\mathrm{x}$ is assumed to be 2) & 0.7 \\
Nitrogen oxide & $\mathrm{NO}$ & 1.07 \\
Ammonia & $\mathrm{NH}_{3}$ & 1.88 \\
Hydrogen fluoride & $\mathrm{HF}$ & 1.6 \\
Hydrogen chloride & $\mathrm{HCl}$ & 0.88 \\
\hline
\end{tabular}

Source: [2] 
Table 2. Equivalency Factor for Trifluoroacetic Acid (TFA) compared to HF and HCl.

\begin{tabular}{cccccc}
\hline Substance & Formula & Reaction & $\begin{array}{c}\text { Molar wt } \\
\mathbf{g} / \mathbf{m o l e}\end{array}$ & $\mathbf{n}$ & $\begin{array}{c}\mathrm{EF} \mathrm{kg} \\
\mathrm{SO}_{2} / \mathbf{k g}\end{array}$ \\
\hline Sulphur dioxide & $\mathrm{SO}_{2}$ & $\mathrm{SO}_{2}+\mathrm{H}_{2} \mathrm{O} \rightarrow 2 \mathrm{H}^{+}+\mathrm{SO}_{3}^{2-}$ & 64.06 & 2 & 1 \\
Hydrogen fluoride & $\mathrm{HF}$ & $\mathrm{HF} \rightarrow \mathrm{H}^{+}+\mathrm{F}^{-}$ & 20.01 & 1 & 1.60 \\
$\begin{array}{c}\text { Trifluoroacetic acid (TFA) } \\
\text { Hydrogen chloride }\end{array}$ & $\mathrm{CF}{ }_{3} \mathrm{COOH}$ & $\mathrm{CF}_{3} \mathrm{COOH} \rightarrow \mathrm{CF}_{3} \mathrm{COO}^{-}+\mathrm{H}^{+}$ & 114.02 & 1 & 0.28 \\
\hline
\end{tabular}

Definition $\mathrm{n}$ is the number of hydrogen ions released as a result of conversion of the substance. Source: [2] except for TFA.

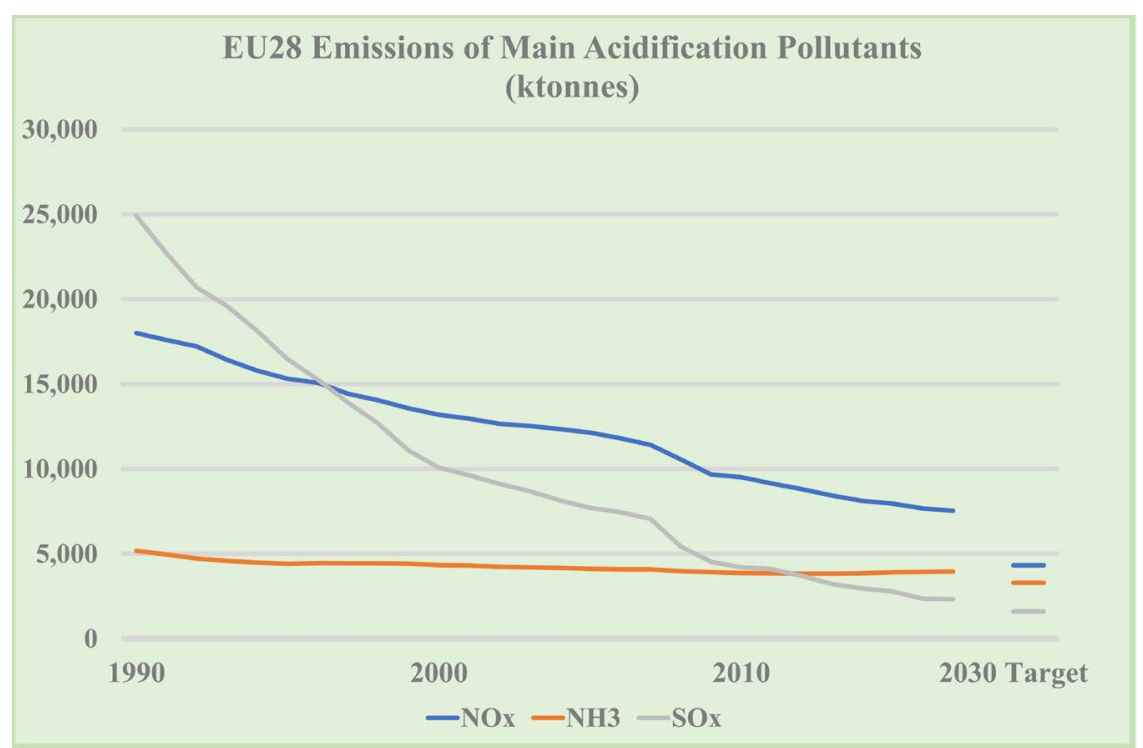

Figure 1. EU28 emissions of the main acidification air pollutants $\left(\mathrm{NO}_{\mathrm{x}}, \mathrm{SO}_{\mathrm{x}}\right.$ and $\left.\mathrm{NH}_{3}\right)$ and 2030 targets. Source: [4].

According to the European Environmental Agency [5], after decades of declining sulphur emissions in Europe, acidification is declining or slowing so that some forests and lakes are showing signs of recovery. Owing to the considerable reductions in emissions of $\mathrm{SO}_{\mathrm{x}}$ over the past three decades, nitrogen compounds emitted as $\mathrm{NO}_{\mathrm{x}}$ have become the principal acidifying components in both terrestrial and aquatic ecosystems, in addition to their role in causing eutrophication. However, emissions of $\mathrm{SO}_{\mathrm{x}}$, which have a higher acidifying potential than $\mathrm{NO}_{\mathrm{x}}$, still contribute to acidification. The 2018 Progress towards the achievement of the EU's air quality and emissions objectives [4] estimated that the further reduction in $\mathrm{SO}_{2}$ emissions in order to comply with the NEC Directive requirements will resolve most of the threat of acidification of forest soils, and full implementation of additional reduction potentials would allow meeting the critical loads for acidification at $99.8 \%$ of all European forest areas.

As the emissions of the main air pollutants contributing to acidification decrease it is important to consider the potential impact of HFCs, HFOs, and HCFOs for acidification. For the emissions of HFCs in the EU, a worst-case sce- 
nario allows their theoretical potential contribution in 2016 to acidification to be estimated and compared to the acidification potential for the main air pollutants contributing to acidification. Assuming, the $\mathrm{EU}$ targets for emissions of $\mathrm{SO}_{2}$, $\mathrm{NO}_{\mathrm{x}}, \mathrm{NH}_{3}$ are achieved by 2030, allows a comparison of the Acidification Potential of forecast emissions HFCs, HFOs and HCFOs with the 2030 target emissions.

Under the EU F-Gas Regulation 517/2014 on fluorinated greenhouse gases, the European Union is gradually reducing the supply of HFCs, weighted for their Global Warming Potential (GWP). Industry has responded by developing short lived fluorinated substances, the hydrofluoro-olefins (HFOs) and hydrochlorofluoro-olefins (HCFOs) with atmospheric lifetimes from days (e.g. HFO-1234yf, 2,3,3,3-tetrafluoroprop-1-ene, $\mathrm{CF}_{3} \mathrm{CF}=\mathrm{CH}_{2}$ ) to months (e.g. $\mathrm{HFO}-1336 \mathrm{mzz}(\mathrm{E})$, cis-1,1,1,4,4,4-hexafluorobut-2-ene, $\mathrm{Cis}-\mathrm{CF}_{3} \mathrm{CH}=\mathrm{CHCF}_{3}$ ). These are replacing $\mathrm{HFCs}$ in some applications due to their environmental, performance and safety properties. The naming convention for fluorocarbon refrigerants (single substances) was developed to allow engineers and non-chemists to easily identify the refrigerant [6].

Acidification is regarded as a regional effect. Widely used HFCs have lifetimes in the range 1.6 years (HFC-152a,1,1-difluoroethane) to 51 years (HFC-143a, 1,1,1-trifluoroethane) for the most widely used HFCs and are well mixed in the atmosphere globally and their degradation does not occur on a regional basis. However, for a worst-case scenario, it is assumed that their atmospheric breakdown is regional and that all the HFCs emitted in the EU breakdown within the EU boundaries, and their theoretical potential contribution to acidification estimated. The short atmospheric lifetimes of the HFOs and HCFOs means that their decomposition is mainly regional and the acid species, including HF [7], generated can be assumed to be deposited within the EU. For the HCFOs, $\mathrm{HCl}$ will also be produced as an atmospheric breakdown product.

The generation and fate of trifluoroacetic acid (TFA), although primarily a natural substance, from breakdown of fluorocarbons including HFCs and HFOs is the subject of a large number of studies [8]. This paper only considers TFA in the context of acidification. Carbon dioxide $\left(\mathrm{CO}_{2}\right)$ is also a breakdown product of some fluorocarbons, but the quantities are minute compared to the $\mathrm{CO}_{2}$ from fossil fuels which contribute to the acidification of the sea [9] as well as global warming.

\section{Other Sources of Atmospheric $\mathrm{HCl}$ and HF}

Most of the $\mathrm{HCl}$ in the lower atmosphere (where acid rain is generated) is the result of acidification of sea salt aerosol [10]. This $\mathrm{HCl}$ therefore does not represent additional $\mathrm{H}^{+}$as it is simply a change of counter-ion from $\mathrm{SO}_{4}$ to $\mathrm{Cl}$. $\mathrm{HCl}$ is also emitted to the atmosphere from volcanic sources.

Fluorine, in the form of fluoride ion, is found in many rocks and minerals and most soils. It comprises $0.06 \%$ of the Earth's crust (which, although it does not 
seem much, is actually about twice the known amount of fossil fuel carbon). Fluorides are released into the environment naturally through the weathering and dissolution of minerals, in emissions from volcanoes and in marine aerosols. Estimates of the annual global release of hydrogen fluoride from volcanic sources through passive degassing and eruptions range from 0.06 to 6 million tonnes/year. The wide distribution in soils means that there is significant natural movement of fluoride through the atmosphere on wind-borne dust particles (estimates vary from 1 to 10 million tonnes/year) [11] [12] [13].

Hydrogen fluoride ( $\mathrm{HF})$ and hydrogen chloride $(\mathrm{HCl})$, are released to air from combustion of fuels [14] that contain trace amounts of fluoride or chloride. Emissions of $\mathrm{HF}$ and $\mathrm{HCl}$ display a similar source pattern with significant emissions from the combustion of coal. As the importance of coal has decreased, the contribution of other sources has grown. Most significant of these is brickmaking as a source of HF. Solid fuels, and particularly coal, do contain chlorine and, as a result, the combustion of coal is responsible for $\mathrm{HCl}$ emissions [15], reduced by the installation of emission controls at coal-fired power stations. Of particular note, the burning of biomass and municipal solid waste (MSW) to generate heat and power contribute to emissions of $\mathrm{HCl}$.

\section{Emissions of HFCs, HFOs and HCFOs}

Emissions from hydrochlorofluorocarbons (HCFCs) in the EU have declined substantially as most of their uses have been banned since 2004 under the EU ODS Regulations (e.g. Regulation 2037/2000 on substances that deplete the ozone layer). Some emissions still occur from refrigeration installations (HCFC-22, chlorodifluoromethane) and decommissioned insulation foam (HCFC-141b, 1,1-dichloro-1fluoro-ethane and HCFC-142b, 1-chloro-1,1-difluoro-ethane) depending on the waste treatment technology. Their atmospheric lifetimes are between 9 and 18 years which means that the formation of $\mathrm{HCl}$ and $\mathrm{HF}$ is gradual and not regional and will fall over time as the "bank" is declining. The HCFCs were replaced by the HFCs which have been used in refrigeration, stationary and mobile air-conditioning, heat pumps, MDIs (metered dose inhalers), insulation foams and some fire-fighting systems since the early 1990s.

\subsection{Emissions of HFCs}

The emission data for HFCs is available as $\mathrm{CO}_{2} \mathrm{e}$ (calculated from the emitted tonnes and the global warming potential (GWP) of each HFC) and in 2016 HFC emissions were reported as 107,067 ktonnes $\mathrm{CO}_{2} \mathrm{e}$. The emissions of HFCs (as $\mathrm{CO}_{2} \mathrm{e}$ ) in the EU are shown in Figure 2. In 2017 about 90\% of HFC emissions, as $\mathrm{CO}_{2} \mathrm{e}$, were from Refrigeration and Air-Conditioning (RAC) [16], as shown in Figure 3. A similar split in sources of emissions will have occurred in the preceding few years. There will be a time-lag between HFCs placed on the market and emissions. The period 2010 to 2014 was selected for average GWPs as HCFCs were effectively banned at end 2009, and there was not significant use of 
EU HFC Emission Estimates

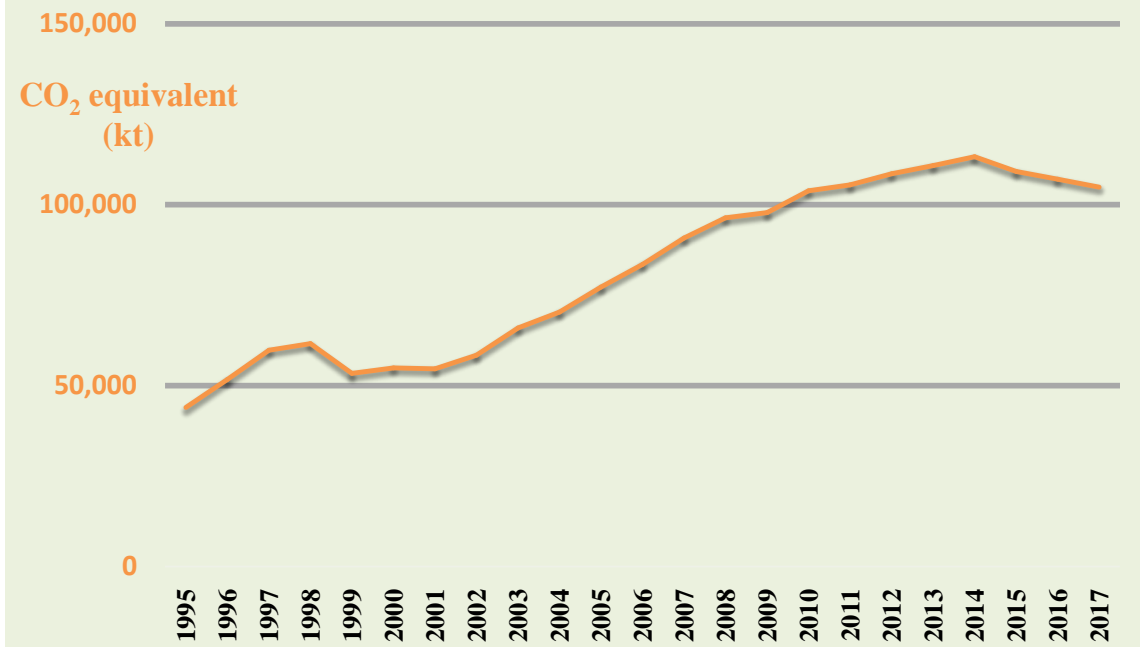

Figure 2. Estimated emissions of HFCs in the EU. Source: [16].

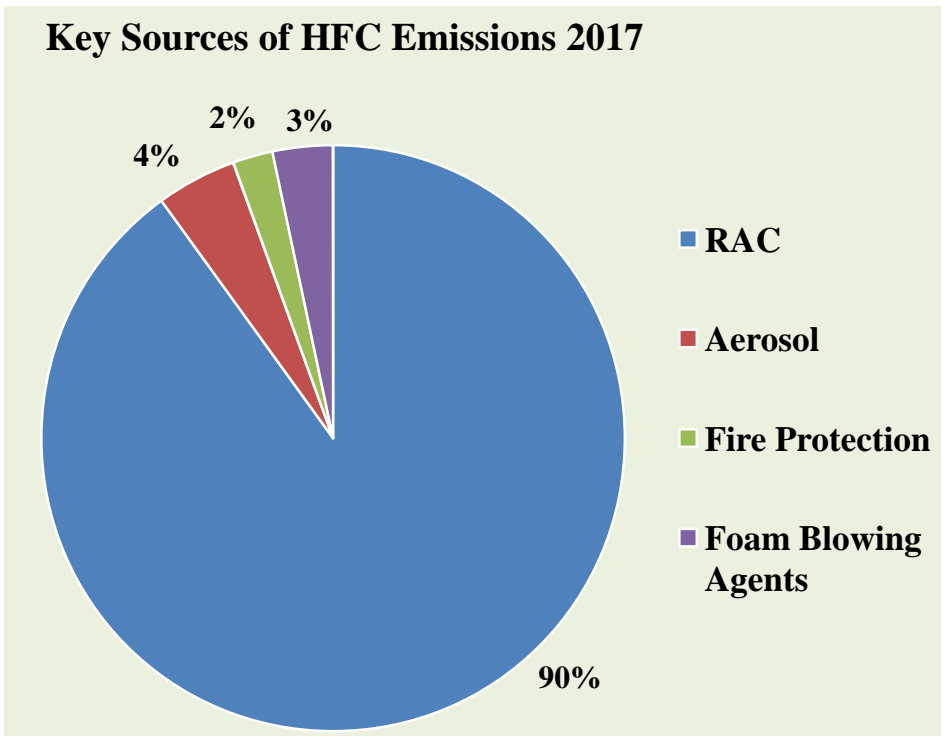

Figure 3. Key sources of HFC emissions, as $\mathrm{CO}_{2} \mathrm{e}$, in 2017 for the EU. Source: [16].

HFOs in this period. Assuming an average GWP of 2100 (based on the average GWPs for HFC placed on the market in the years 2010 to 2014 [17] (average GWPs 2152 to 2062), allows an estimate of the actual tonnes of HFC emissions in 2016 at about 51,000 tonnes.

\subsection{Switch to Short Lived Hydrofluoro-Olefins (HFOs) and Hydrochlorofluoro-Olefins (HCFOs)}

Under the EU F-Gas regulation (517/2014), the European Union is gradually reducing the supply of HFCs, weighted for their Global Warming Potential (GWP). As the use of HFCs decreases due to the F-Gas Regulation, the use of HFOs and HCFOs is expected to continue to increase. Figure 4 shows the HCFCs, HFCs 


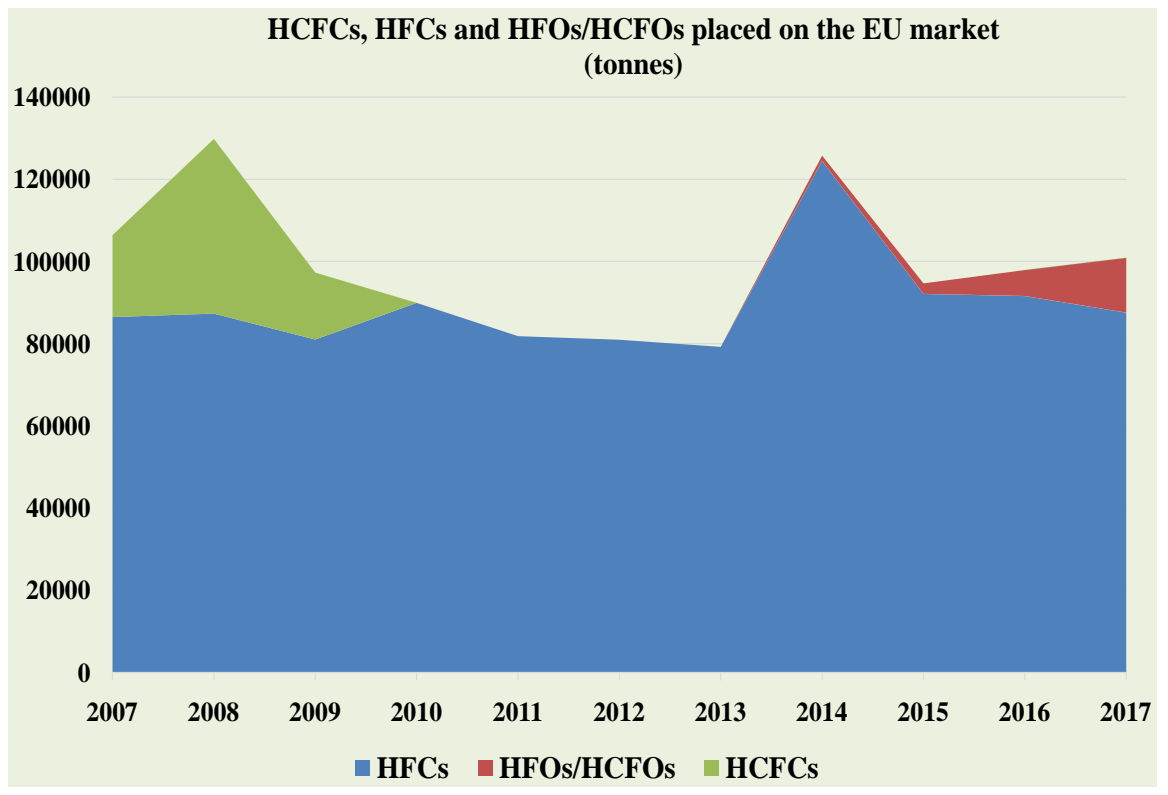

Figure 4. HCFCs, HFCs, HFOs and HCFOs placed on the EU market. Source: [17].

and HFOs/HCFOs placed on the EU market since 2007 [17] and does not show a significant increasing trend for these fluorocarbons in total. The two peaks occur in advance of market restrictions, the HCFC phase-out and the start of the HFC phase-down. The average tonnes of HCFCs, HFCs, and HFOs/HCFOs placed on the EU market in each year since 2007 , is 98,590 tonnes, similar to the quantity $(100,854$ tonnes) placed on the market in 2017. As RAC containment and recycling improves and some applications move to non-fluorocarbons alternatives it is unlikely that fluorocarbon use will increase over the next years to 2030 and may potentially decrease, particularly as improved containment, recycling and destruction should also contribute to reduction in emissions of all these fluorocarbons. The worst-case scenario selected for 2030 as HFCs are phased-down and HFOs/HCFOs use increases is the same total emissions of HFCs/HFOs/HCFOs as for HFCs in 2016, assuming all HFCs/HFOs/HCFOs emitted breakdown within the EU boundaries and their theoretical potential contribution to acidification estimated.

Emissions in 2030 will be influenced by the HFCs, HFOs and HCFOs placed on the market several years earlier. Their contributions to the forecast emissions in 2030 are derived from a recent model for consumption and emissions of HFCs and HFOs. In addition, a range of emissions of HFO-1234yf (2,3,3,3-tetrafluoroprop-1-ene, $\mathrm{CF}_{3} \mathrm{CF}=\mathrm{CH}_{2}$ ) have been taken into account. The paper [18] "Future Emissions and Atmospheric Fate of HFC-1234yf from Mobile Air Conditioners in Europe" estimated total predicted emissions of HFC-1234yf for the EU27 countries for the year 2020, assuming complete conversion to HFO-1234yf, to be 9800 tonnes to 17,200 tonnes per year. The more recent model suggests that HFO-1234yf emissions could be towards the lower end of the range, even allowing for additional emissions of HFO-1234yf from its use in blended refri- 
gerants and for other RAC applications. The impacts of lower and higher emissions of HFO-1234yf are compared to the base case for the relative acidification potential. In 2025, the placing on the market quota for HFCs reduces to $31 \%$, which will have a major effect on the refrigerants that can be made available under the phase-down cap. The reduction in the HFC cap is resulting in a switch to refrigerants with lower GWPs. Several of the lower GWP refrigerants that are being adopted as replacements for HFCs contain HFO-1234yf as a component (e.g. R-448A, R-449A, R-452A, R-452B, R-454C, R-455C, R-457C and R-513A). Therefore there will be some emissions of HFO-1234yf from stationary refrigeration, air-conditioning and heat pumps (RACHP) as well as mobile air-conditioning (MAC). In addition, there will be increased installed equipment using HFC-32 (difluoromethane) instead of R-410A, and refrigerants containing HFC143a (mainly R-404A) will have substantially been replaced. The naming convention for series 400 and series 500 refrigerants allow engineers and non-chemists to easily identify the refrigerant as they contain two or more components. The composition of these refrigerants is available [19].

\subsection{Atmospheric Formation of $\mathrm{HF}, \mathrm{HCl}$ and TFA from HFCs/HFOs/HCFOs Emitted in the EU}

The atmospheric chemistry of degradation of fluorocarbons is well documented [20]. The table shows the weighted average HF generation assuming that the HFCs breakdown to form HF exclusively rather than some minor quantities of trifluoroacetic acid (TFA) (from HFC-134a). This is a worst-case scenario for acidification potential as it generates the maximum moles of acid per mole of HFC. Table 3 is derived from available 2014 HFC placing on the market data [21] and shows the average maximum HF generation per tonne of HFC as 0.78 tonnes per tonne.

The actual total HFCs placed on the EU market is higher than shown in Table 3 and is reported as 124,408 tonnes in 2014. Confidentiality means some individual HFC quantities are not disclosed. In addition, for this simple analysis, HFC-227ea (1,1,1,2,3,3,3-heptafluoropropane) has been excluded as it breaks-down to produce one molecule of TFA per molecule of HFC-227ea. However, the quantities of HFC-227ea placed on the market mean that it would have a very minor effect on the calculation. The total weighted average HF content is 0.78 , the individual averages sum to 0.77 (a rounding issue).An alternative method of determining the maximum HF generation rate per tonne is from the three dominant HFC refrigerants placed on the EU market in 2014, which are R-134a, $\mathrm{R}-404 \mathrm{~A}$ and R-410A. This is shown in Table 4, giving effectively the same result.

As these refrigerants may have different emission rates due to their use in different types of equipment and for HFC-134a, its use in mobile air-conditioning and MDIs, their similar acid generation rates ensures that the worst-case scenario calculation is applicable, particularly as HFC-134a is about $50 \%$ of the HFCs placed on the EU market in 2014. 
Table 3. Weighted average worst case HF Generation for HFC placed on the market in 2014.

\begin{tabular}{ccccccc}
\hline HFC & Formula & 2014 tonnes & MWt & Moles HF & HF by wt & $\begin{array}{c}\text { Weighted average } \\
\text { HF content }\end{array}$ \\
\hline $152 \mathrm{a}$ & $\mathrm{C}_{2} \mathrm{~F}_{2} \mathrm{H}_{4}$ & 6227 & 66 & 2 & 0.61 & 0.03 \\
$134 \mathrm{a}$ & $\mathrm{C}_{2} \mathrm{H}_{2} \mathrm{~F}_{4}$ & 60,771 & 102 & 4 & 0.78 & 0.41 \\
$143 \mathrm{a}$ & $\mathrm{C}_{2} \mathrm{H}_{3} \mathrm{~F}_{3}$ & 13,512 & 84 & 3 & 0.71 & 0.08 \\
125 & $\mathrm{C}_{2} \mathrm{HF}_{5}$ & 25,476 & 120 & 5 & 0.83 & 0.18 \\
32 & $\mathrm{CH}_{2} \mathrm{~F}_{2}$ & 11,060 & 52 & 2 & 0.77 & 0.07 \\
& Total & $\mathbf{1 1 7 , 0 4 6}$ & & & & $\mathbf{0 . 7 8}$ \\
\hline
\end{tabular}

Source: [21].

Table 4. Maximum HF generation from the three main refrigerants in 2014 (assumes no TFA generated).

\begin{tabular}{ccc}
\hline Refrigerant & Formula \& Composition & HF by wt \\
\hline R-134a & $\mathrm{CF}_{3} \mathrm{CFH}_{2}$ & 0.78 \\
R-404A & $\mathrm{C}_{2} \mathrm{~F}_{5} \mathrm{H} / \mathrm{C}_{2} \mathrm{~F}_{3} \mathrm{H}_{3} / \mathrm{CF}_{3} \mathrm{CFH}_{2}(44.0 / 52.0 / 4.0)$ & 0.77 \\
R-410A & $\mathrm{CH}_{2} \mathrm{~F}_{2} / \mathrm{C}_{2} \mathrm{~F}_{5} \mathrm{H}(50.0 / 50.0)$ & 0.80 \\
\hline
\end{tabular}

\subsection{Acid Generation from HFCs, HFOs and HCFOs}

Each molecule of HFO-1234yf (2,3,3,3-tetrafluoroprop-1-ene, $\left.\mathrm{CF}_{3} \mathrm{CF}=\mathrm{CH}_{2}\right)$ breaksdown in the atmosphere to produce 1 molecule of TFA [8], [22], which reduces the generation of acids as less fluoride is available to generate HF. HFC-134a (1,1,1,2-tetrafluoroethane, $\mathrm{CH}_{2} \mathrm{FCF}_{3}$ ) breaks down to produce a $21 \%$ yield of TFA. Yields of TFA from HFCs, HFOs and HCFOs are shown in Table 5 [23] [24] [25].

Table 6 shows the acid generation potential for the HFCs, HFOs and HCFOs that are forecast to be emitted in 2030 as the use pattern of fluorocarbons changes in response to the F-Gas Regulation.

The refrigerants adopted more widely in the period up to 2030 will be lower GWP single components and blends of some of the substances in Table 6. Some of these substances will also be used as propellants and foam blowing agents (and may also be blended with non-fluorocarbons). The trend is to use lower GWP refrigerants as replacements for R-404A, R-410A and R-134a (the most widely installed refrigerants). Table 7 shows the range of refrigerants that might be used as their replacements and these have lower acid generation.

\section{Potential Contributors to Acidification/Acidification Potential}

Acidification Potential (AP) is based on the contributions of $\mathrm{SO}_{2}, \mathrm{NO}_{x}, \mathrm{HCl}$, $\mathrm{NH}_{3}, \mathrm{HF}$ and other acids (or acid precursors) make to the potential acid deposition, i.e. on their potential to form $\mathrm{H}^{+}$ions [26] and is calculated from the Equivalency Factor and the emissions of each substance. 
Table 5. Atmospheric Breakdown: Molar yields of TFA from HFCs, HFOs and HCFOs.

\begin{tabular}{ccc}
\hline Designation & Formula & TFA molar yield \\
\hline HFC-134a & $\mathrm{CF}_{3} \mathrm{CFH}_{2}$ & $21 \%$ \\
HFC-227ea & $\mathrm{CF}_{3} \mathrm{CHFCF}_{3}$ & $100 \%$ \\
HFC-236fa & $\mathrm{CF}_{3} \mathrm{CH}_{2} \mathrm{CF}_{3}$ & $<10 \%$ \\
HFC-245fa & $\mathrm{CF}_{3} \mathrm{CH}_{2} \mathrm{CHF}_{2}$ & $<10 \%$ \\
HFC-365mfc & $\mathrm{CH}_{3} \mathrm{CF}_{2} \mathrm{CH}_{2} \mathrm{CF}_{3}$ & $<10 \%$ \\
HFO-1234yf & $\mathrm{CF}_{3} \mathrm{CF}^{-\mathrm{CH}_{2}}$ & $100 \%$ \\
HFO-1234ze(E) & $\mathrm{Trans}_{-} \mathrm{CF} \mathrm{CH}^{-} \mathrm{CFH}_{2}$ & $0 \%$ \\
HCFO-1233zd(E) & Trans-CHCl $=\mathrm{CHCF}_{3}$ & $0 \%$ experimental, \\
\end{tabular}

Other atmospheric breakdown products include naturally occurring $\mathrm{HCOOH}$ (formic acid) $\mathrm{HF}, \mathrm{HCl}, \mathrm{CO}_{2}$. The TFA yields have been determined using models and/or laboratory experiments.

Table 6. Acid generation potential for the HFCs, HFOs and HCFOs forecast to be emitted in 2030.

\begin{tabular}{ccccccccc}
\hline Substance & Formula & MWt & $\begin{array}{c}\text { Moles } \\
\text { HF }\end{array}$ & HF by wt & $\begin{array}{c}\text { Moles } \\
\text { TFA }\end{array}$ & $\begin{array}{c}\text { TFA by } \\
\text { wt }\end{array}$ & $\begin{array}{c}\text { Moles } \\
\text { HCl }\end{array}$ & $\begin{array}{c}\text { HCl by } \\
\text { wt }\end{array}$ \\
\hline HFO-1234yf & $\mathrm{C}_{3} \mathrm{~F}_{4} \mathrm{H}_{2}$ & 114 & 1 & 0.18 & 1 & 1 & 0 & 0 \\
HFO-1234zeE & $\mathrm{C}_{3} \mathrm{~F}_{4} \mathrm{H}_{2}$ & 114 & 4 & 0.70 & 0 & 0 & 0 & 0 \\
HFO-1336mzz & $\mathrm{C}_{4} \mathrm{~F}_{6} \mathrm{H}_{2}$ & 164 & 6 & 0.73 & 0 & 0 & 0 & 0 \\
HCFO-1233zd & $\mathrm{C}_{3} \mathrm{~F}_{3} \mathrm{ClH}_{2}$ & 130.5 & 3 & 0.46 & 0 & 0 & 1 & 0.28 \\
HFC-32 & $\mathrm{CH}_{2} \mathrm{~F}_{2}$ & 52 & 2 & 0.77 & 0 & 0 & 0 & 0 \\
HFC-125 & $\mathrm{C}_{2} \mathrm{~F}_{5} \mathrm{H}$ & 120 & 5 & 0.83 & 0 & 0 & 0 & 0 \\
HFC-134a & $\mathrm{C}_{2} \mathrm{~F}_{4} \mathrm{H}_{2}$ & 102 & 3.37 & 0.66 & 0.21 & 0.23 & 0 & 0 \\
HFC-152a & $\mathrm{C}_{2} \mathrm{~F}_{2} \mathrm{H}_{4}$ & 66 & 2 & 0.61 & 0 & 0 & 0 & 0 \\
HFC-143a & $\mathrm{C}_{2} \mathrm{~F}_{3} \mathrm{H}_{3}$ & 84 & 3 & 0.71 & 0 & 0 & 0 & 0 \\
HFC-227ea & $\mathrm{C}_{3} \mathrm{HF}_{7}$ & 170 & 4 & 0.47 & 1 & 0.67 & 0 & 0 \\
\hline
\end{tabular}

Table 7. Potential acid generation for key HFC refrigerants and their lower GWP replacements.

\begin{tabular}{ccccc}
\hline & Refrigerant Composition (Mass \%) & HF by wt & $\begin{array}{c}\text { TFA by } \\
\text { wt }\end{array}$ & $\begin{array}{c}\text { GWP } \\
\text { F-Gas AR4* }\end{array}$ \\
& R-404A and replacement fluorocarbon refrigerants & & \\
R-404A & R-125/143a/134a $(44.0 / 52.0 / 4.0)$ & 0.76 & 0.01 & 3922 \\
R-407A & R-32/125/134a $(20.0 / 40.0 / 40.0)$ & 0.75 & 0.09 & 2107 \\
R-407F & R-32/125/134a $(30.0 / 30.0 / 40.0)$ & 0.73 & 0.12 & 1825 \\
R-452A & R-32/125/1234yf $(11.0 / 59.0 / 30.0$ & 0.63 & 0.30 & 2140 \\
R-448A & R-32/125/1234yf/134a/1234ze(E) & & & 1387 \\
R-449A & $(26.0 / 26.0 / 20.0 / 21.0 / 7.0)$ & 0.64 & 0.25 & 1397
\end{tabular}




\begin{tabular}{|c|c|c|c|c|}
\hline \multicolumn{5}{|l|}{ Continued } \\
\hline $\mathrm{R}-460 \mathrm{~B}$ & R-32/125/134a/1234ze(E) $(28.0 / 25.0 / 20.0 / 27.0)$ & 0.74 & 0.05 & 1352 \\
\hline $\mathrm{R}-454 \mathrm{C}$ & $\mathrm{R}-32 / 1234 \mathrm{yf}(21.5 / 78.5)$ & 0.31 & 0.79 & 148 \\
\hline $\mathrm{R}-455 \mathrm{~A}$ & $\mathrm{R}-744 / 32 / 1234 \mathrm{yf}(3.0 / 21.5 / 75.5)$ & 0.30 & 0.76 & 148 \\
\hline $\mathrm{R}-457 \mathrm{~A}$ & $\mathrm{R}-32 / 1234 \mathrm{yf} / 152 \mathrm{a}(18.0 / 70.0 / 12.0)$ & 0.34 & 0.70 & 139 \\
\hline \multicolumn{5}{|c|}{$\mathrm{R}-410 \mathrm{~A}$ and replacement fluorocarbon refrigerants } \\
\hline $\mathrm{R}-410 \mathrm{~A}$ & $\mathrm{R}-32 / 125(50.0 / 50.0)$ & 0.80 & 0.00 & 2088 \\
\hline $\mathrm{R}-32$ & & 0.77 & 0.00 & 675 \\
\hline $\mathrm{R}-452 \mathrm{~B}$ & R-32/125/1234yf (67.0/7.0/26.0) & 0.62 & 0.26 & 698 \\
\hline \multicolumn{5}{|c|}{$\mathrm{R}-134 \mathrm{a}$ and replacement fluorocarbon refrigerants } \\
\hline $\mathrm{R}-134 \mathrm{a}$ & & 0.66 & 0.23 & 1430 \\
\hline $\mathrm{R}-450 \mathrm{~A}$ & R-134a/1234ze(E) (42.0/58.0) & 0.68 & 0.10 & 605 \\
\hline $\mathrm{R}-513 \mathrm{~A}$ & $\mathrm{R}-1234 \mathrm{yf} / 134 \mathrm{a}(56.0 / 44.0)$ & 0.39 & 0.66 & 631 \\
\hline $\mathrm{R}-1234 \mathrm{yf}$ & & 0.18 & 1.00 & $<1$ \\
\hline $\mathrm{R}-1234 \mathrm{ze}(\mathrm{E})$ & & 0.70 & 0.00 & $<1$ \\
\hline
\end{tabular}

*Note: All GWPs are calculated using the values given in the F-Gas Regulation 517/2014. However, the values listed for the individual substances R-1234yf and R-1234ze(E) are IPCC AR5 values. Source: [18] for refrigerant compositions.

\subsection{Acidification Potential of HFC, HFO and HCFO Emissions in the EU}

Table 8 shows the 2016 AP based on worst-case emissions of HF from HFCs and the 2030 forecast AP based on worst-case emissions of $\mathrm{HF}, \mathrm{HCl}$ and TFA due to emissions of HFC, HFOs and HCFOs, from a recent model of their forecast consumption and emissions. The acidification potential (AP) per tonne of $\mathrm{HFC} / \mathrm{HFO} / \mathrm{HCFO}$ emissions in 2030 is forecast to have decreased significantly compared to 2016, in part due to the lower generation of acids from each molecule of R-1234yf.

\subsection{Acidification Potential of Emissions of $\mathrm{SO}_{2}, \mathrm{NO}_{\mathrm{x}}, \mathrm{NH}_{3}$ in the $\mathrm{EU}$}

The EU has published 2016 emissions [27] of $\mathrm{SO}_{2}, \mathrm{NO}_{\mathrm{x}}, \mathrm{NH}_{3}$ and targets for 2030 [4]. The Acidification Potentials of these substances are shown in Table 9.

\section{Conclusions: Relative Acidification Potential of HFCs, HFOs and HCFOs}

Assuming that the EU targets for 2030 are achieved allows a comparison of the Acidification Potential of HFCs, HFOs, and HCFOs emissions with the 2030 target emissions in addition to a comparison for emissions in 2016. Table 10 shows the relative contribution in 2016 and the forecast contribution in 2030 for HFCs, HFOs and HCFOs compared to the Acidification Potential for the main air pollutants contributing to acidification. The reduction in AP from the estimated change in fluorocarbon emissions composition broadly matches the 2030 
Table 8. Acidification Potentials for fluorocarbon emissions in 2016 and 2030.

\begin{tabular}{|c|c|c|c|c|}
\hline & Acid Generation per tonne & $\mathrm{EF} \mathrm{kg} \mathrm{SO} / \mathrm{kg}$ & AP/tonne & AP (ktonnes) \\
\hline \multicolumn{5}{|c|}{2016 HFCs 51,000 tonnes emissions } \\
\hline HF (2016) & 0.78 & 1.6 & 1.25 & 63.321 \\
\hline \multicolumn{5}{|c|}{2030 HFCs, HFOs, HCFOs 51,000 tonnes emissions } \\
\hline $\mathrm{HF}$ & 0.52 & 1.6 & 0.83 & 42.530 \\
\hline TFA & 0.39 & 0.28 & 0.11 & 5.547 \\
\hline $\mathrm{HCl}$ & 0.01 & 0.88 & 0.01 & 0.369 \\
\hline Total (2030) & & & 0.95 & 48.446 \\
\hline
\end{tabular}

Table 9. EU 2016 Emissions and 2030 Targets for $\mathrm{SO}_{2}, \mathrm{NO}_{\mathrm{x}}, \mathrm{NH}_{3}$.

\begin{tabular}{cccc}
\hline & $\mathrm{EF} \mathrm{kg} \mathrm{SO}_{2} / \mathrm{kg}$ & $\begin{array}{c}\text { Emissions } \\
\text { (ktonnes) }\end{array}$ & $\begin{array}{c}\mathrm{AP} \\
\text { (ktonnes) }\end{array}$ \\
\hline $\mathrm{SO}_{2}$ & 2016 Emissions & & \\
$\mathrm{NO}_{\mathrm{x}}$ & 1 & 2329 & 2329 \\
$\mathrm{NH}_{3}$ & 0.70 & 7163 & 5014 \\
$\mathrm{Total}$ & 1.88 & 3906 & 7343 \\
& & 13,398 & 14,686 \\
$\mathrm{SO}_{2}$ & 1 & 1604.17 & 1604.17 \\
$\mathrm{NO}_{\mathrm{x}}$ & 0.7 & 4326.58 & 3028.61 \\
$\mathrm{NH}_{3}$ & 1.88 & 3297.89 & 6200.03 \\
$\mathrm{Total}$ & & 9228.64 & $10,832.81$ \\
\hline
\end{tabular}

Source: [4].

Table 10. Relative contribution to acidification for HFCs, HFOs and HCFOs.

\begin{tabular}{ccc}
\hline & 2016AP (ktonnes) & 2030 AP (ktonnes) \\
\hline $\mathrm{SO}_{2} \mathrm{NO}_{\mathrm{x}} \mathrm{NH}_{3}$ & 14686 & 10833 \\
HFCs HFOs HCFOs & 63.3 & 48.4 \\
Relative HFCs HFOs HCFOs & $0.43 \%$ & $0.45 \%$ \\
\hline
\end{tabular}

Data from Table 8 and Table 9.

reduction targets for the $\mathrm{EU}$ for $\mathrm{SO}_{2}, \mathrm{NO}_{\mathrm{x}}, \mathrm{NH}_{3}$. For both 2016 and 2030 the relative APs due to HFCs, HFOs and HCFOs are very similar and are estimated at less than $0.5 \%$. The lower and higher emissions scenarios for HFO-1234yf result in relative acidification potentials of $0.42 \%$ and $0.47 \%$ for emissions in 2030 , compared to $0.45 \%$ for the base-case. It can be concluded that these fluorocarbons have an insignificant contribution to acidification at present and in 2030 .

Furthermore, the "2018 Progress towards the achievement of the EU's air quality and emissions objectives" [4] estimated that the further reduction in $\mathrm{SO}_{2}$ 
emissions in order to comply with the NEC Directive requirements will resolve most of the threat of acidification of forest soils, and full implementation of additional reduction potentials would allow meeting the critical loads for acidification at $99.8 \%$ of all European forest areas. This supports the important conclusion that HFCs, HFOs and HCFOs emissions will make an insignificant contribution to acidification.

\section{Disclaimer}

The work and opinions expressed in this paper are those of the authors in a personal capacity

\section{Conflicts of Interest}

The authors declare no conflicts of interest regarding the publication of this paper.

\section{References}

[1] Stranddorf, H.K., Hoffmann, L. and Schmidt, A. (2005) Update on Impact Categories, Normalisation and Weighting in LCA-Selected EDIP97-Data FORCE Technology Environmental Project Nr. 995 Miljøprojekt.

[2] Hauschild, M. and Wenzel, H. (1998) Acidification as a Criterion in the Environmental Assessment of Products. In: Hauschild, M. and Wenzel, H., Eds., Environmental Assessment of Products, Volume 2 Scientific background, Chapman \& Hall, London.

[3] European Environment Agency (EEA) (2019) The Air Pollutant Emissions Data Viewer (LRTAP Convention) Provides Access to the Data Contained in the EU Emission Inventory Report 1990-2016 under the UNECE Convention on Long-Range Transboundary Air Pollution (LRTAP)

https://www.eea.europa.eu/data-and-maps/dashboards/air-pollutant-emissions-dat a-viewer-2

[4] EEA (2018) Air Quality in Europe-2018 European Environment Agency (EEA) Report.

[5] European Environment Agency (EEA) (2018) EU progress in Meeting 2010 Emission Ceilings Set out in the NEC Directive and the 2020/2030 Reduction Commitments.

https://www.eea.europa.eu/themes/air/national-emission-ceilings/nec-directive-rep orting-status-2018

[6] CEFIC (2016) (H)(C)FC and HFO Nomenclature-Basic Principles. https://www.fluorocarbons.org/wp-content/uploads/2016/09/EFCTC_Learn_about_ HCFC_HFC_HFO_nomenclature.pdf

[7] Wallington, T.J., Sulbaek Andersen, M.P. and Nielsen, O.J. (2015) Atmospheric Chemistry of Short-Chain Haloolefins: Photochemical Ozone Creation Potentials (POCPs), Global Warming Potentials (GWPs), and Ozone Depletion Potentials (ODPs). Chemosphere, 129, 135-141. https://doi.org/10.1016/j.chemosphere.2014.06.092

[8] The World Meteorological Organization Global Ozone Research and Monitoring Project, Report No. 58, Scientific Assessment of Ozone Depletion (2018) Chapters 2 (HFCs) and 6 (Scenarios and Information for Policy Makers). 
[9] IEAE (2018) Ocean Acidification in the IPCC Special Report: Global Warming of $1.5^{\circ} \mathrm{C}$. https://news-oceanacidification-icc.org/2018/10/08/ocean-acidification-in-the-ipccspecial-report-global-warming-of-1-5c/

[10] Erickson III, D.J. and Christophe Seuzaret, C. (1999) A General Circulation Model Based Calculation of $\mathrm{HCl}$ and $\mathrm{ClNO}_{2}$ Production from Sea Salt Dechlorination: Reactive Chlorine Emissions Inventory. Journal of Geophysical Research, 104, 83478372. https://doi.org/10.1029/98JD01384

[11] EFCTC (2013) Learn about Environment \& Breakdown Products: Fluoride in the Atmosphere: A Very Small Contribution from HFCs.

https://www.fluorocarbons.org/wp-content/uploads/2016/09/EFCTC_Learn_about_ Fluoride_in_atm_small_HFC_contribution.pdf

[12] Friend, J.P. (1989) Scientific Assessment in the AFEAS Report-Chapter 11, Natural Sources. Natural Chlorine and Fluorine in the Atmosphere, Water and Precipitation.

[13] Lobert, J.M., Keene, W.C., Logan, J.A. and Yevich, R. (1999) Global Chlorine Emissions from Biomass Burning: Reactive Chlorine Emissions Inventory. Journal of Geophysical Research, 104, 8373-8389. https://doi.org/10.1029/1998JD100077

[14] NAEI (2016) National Atmospheric Emissions Inventory for Hydrogen Fluoride and Hydrogen Chloride. http://naei.beis.gov.uk/overview/index

[15] McCulloch, A., Aucott, M.L., Benkovitz, C.M., Graedel, T.E., Kleiman, G., Midgley, P.M. and Li, Y.-F. (1999) Global Emissions of Hydrogen Chloride and Chloromethane from Coal Combustion, Incineration and Industrial Activities: Reactive Chlorine Emissions Inventory. Journal of Geophysical Research, 104, 8391-8403. https://doi.org/10.1029/1999JD900025

[16] European Environment Agency EEA/PUBL/2019/051 (2019) Annual European Union Greenhouse Gas Inventory 1990-2017 and Inventory Report 2019. Submission under the United Nations Framework Convention on Climate Change and the Kyoto Protocol.

[17] EFCTC (2019) Average GWP Continues to Fall and EU Emissions Decrease, HFC/HFO Data EEA Report No 21/2018, Fluorinated Greenhouse Gases in 2018. HCFC Data in ODP Tonnes (Assumes All HCFC-22) from UNEP Ozone Secretariat Data Centre. https://www.fluorocarbons.org/mediaroom/average-gwp-continues-to-fall-and-euhfc-emissions-decrease/ https://ozone.unep.org/

[18] Henne, S., Dudley, E. Shallcross, D.E., Reimann, S., Xiao, P., Brunner, D., O’Doherty, S. and Buchmann, B. (2012) Future Emissions and Atmospheric Fate of HFC-1234yf from Mobile Air Conditioners in Europe. Environmental Science \& Technology, 46, 1650-1658. https://doi.org/10.1021/es2034608

[19] EFCTC (2018) Refrigerants Subject to the F-Gas Regulation. https://www.fluorocarbons.org/chemical-families/\#.XWfoK3dFw2w

[20] Wallington, T.J., Schneider, W.F., Worsnop, D.R., Nielsen, O.J., Sehested, J., Debruyn, W.J. and Shorter, J.A. (1994) The Environmental Impact of CFC Replacements HFCs and HCFCs. Environmental Science and Technology, 28, 320-326. https://doi.org/10.1021/es00056a714

[21] European Environment Agency EEA Report No 21/2018 (2018) Fluorinated Greenhouse Gases in 2018.

[22] EFCTC (2019) Learn about TFA: For a Wide Range of Information about Trifluoroacetic Acid/Acetate as a Breakdown Product of Some HFCs and Some HFOs. https://www.fluorocarbons.org/wp-content/uploads/2019/05/EFCTC-Learn-AboutTFA-2019F-1.pdf 
[23] World Meteorological Organization (2010) Global Ozone Research and Monitoring Project Report No. 52. Scientific Assessment of Ozone Depletion.

https://www.wmo.int/pages/prog/arep/gaw/ozone_2010/documents/Ozone-Assess ment-2010-complete.pdf

[24] Solomon, K.R., Velders, G.J.M., Wilson, S.R., Madronich, S., Longstreth, J. and Aucamp, P.J. (2016) Sources, Fates, Toxicity, and Risks of Trifluoroacetic Acid and Its Salts: Relevance to Substances Regulated under the Montreal and Kyoto Protocols. Journal of Toxicology and Environmental Health, Part B Critical Reviews, 19, 289 304. https://doi.org/10.1080/10937404.2016.1175981

[25] Nilsson, E.J.K., Nielsen, O.J., Johnson, M.S., Hurley, M.D. and Wallington, T.J. (2009) Atmospheric Chemistry of CIS-CF3CH=CHF: Kinetics of Reactions with $\mathrm{OH}$ Radicals and $\mathrm{O}_{3}$ and Products of $\mathrm{OH}$ Radical Initiated Oxidation. Chemical Physics Letters, 473, 233-237. https://doi.org/10.1016/j.cplett.2009.03.076

[26] Azapagic, A., Emsley, A.L. and Hamerton, L. (2003) Polymers, the Environment and Sustainable Development. John Wiley \& Sons, Ltd., New York. https://doi.org/10.1002/0470865172

[27] European Environment Agency (EEA) NEC (2016) Report. https://www.eea.europa.eu/themes/air/national-emission-ceilings/nec-directive-rep orting-status-2018 